\title{
Prophetic dimension in API Tauhid Novel by Habiburrahman El Shirazy
}

\author{
Fatmawati, Andayani, Raheni Suhita
}

Department of Indonesian Education, Sebelas Maret University, Surakarta, Indonesia

\begin{abstract}
This study aims to describe the prophetic dimension contained in Habiburrahman El Shirazy's Api Tauhid novel. This research is classified as a descriptive qualitative research. Describing the prophetic dimension in this novel uses Kuntowijaya's perspective of prophetic literature. This study concludes that the prophetic dimension in the Api Tauhid novel there are three aspects, namely humanization, liberation, and transcendence. The humanization dimension is an attitude to help and respect each other. Dimensions of liberation include knowledge systems, social systems, and political systems. The liberation of the knowledge system in the form of the establishment of schools and universities, the liberation of the social system in the form of preventing Governor Van from drinking wine, while liberating the political system in the form of liberating the political system of absolute government towards a free and independent government. The dimensions of transcendence, including aspects of patience, fear of God (khauf), very hopeful (raja'), surrender (tawakkal), gratitude, and sincere.
\end{abstract}

Keywords - prophetic dimension, humanization, liberation, transcendence.

\section{INTRODUCTION}

There is a fact written by Herbet Mercuse that modern humans adore technology so much that they forget the human nature and nobleness of their minds. As such, they only understand themselves from the perspective of mere material dimensions. They are trapped in a technocratic rational framework. This perspective makes humans one-dimensional humans (one-dimensional man).

Modern humans are people who are awakened from the influence of technology through industrial machinery, then the use of technology through industrial machinery, then the use of technology is widespread in societies outside industry, such as the diverse use of the words "engineering" and "machinery" in various fields, such as economic machinery, bureaucratic machinery, political machinery, and party machinery [1]There are writing techniques, painting techniques, and so on. There are human techniques through education, upgrading, and courses, courses. That makes the behavior of human machines (I homme machine) is no longer based on common sense, values, and norms. Seeing the development of human behavior that makes a philosopherpoet, Muhammad Iqbal called back about the majesty, strength, and excitement of human life. For that matter, he called for the importance of rebuilding religious thought in Islam [2]. In the field of Philosophy, Roger Garaudy through his famous book, the Promises of Islam [3]questioned analytic philosophy and rationalism or historian which was stuck. This is due to the epistemology of dubious analytic philosophy. His excesses alienate people from God and even themselves.

The problems of social life like this initiated Kuntowijaya to call for prophetic social science. He wants religious values to be the basis of social life [4]. He also argues that prophetic social science will change social life based on certain ethical and prophetic ideals. That is, change is not limited to mere change. Prophetic social sciences contain the values and ideals of change that society aspires to. For Muslims, the intended change is one based on the prophetic ideals of amar ma'ruf, nahi mungkar and tu'minuna billah, as stated in the Qur'an, sura Ali Imran verse 110.

As an empirical fact, thoughts about professionalism can be recognized through discourse, ideas, behavior, and manners represented in various cultural dialectics. One of them is through literary works, both in the form of poetry and prose which include novels and romance. Literary works are written by writers, in which writers live in the middle of their social reality. Therefore between writers as individual beings and as social people influence each other. Thus the writers are inseparable from the life around them and their communities, both as a custom, culture and as a religious community. Therefore, what and how writers write their literary works is part of human response to natural and cultural realities for humans. From there, literature is written as a form of communication that intends and seeks so that the 
reader understands the urgency of doing amar ma'ruf, nahi munkar and tu'minuna billah. the term prophetic literature was born because of the meeting of missionary mission and prophetic role. Prophetic literature contains prophetic values [5].

Seeing the cultural development of this society, researchers are of the view that religious literature, also called prophetic literature, has an ideological function that is considered capable of giving direction to cultural reality. In this context, the Api Tauhid novel by Habiburrahman El Shirazy becomes very important to be studied and researched because of this novel views and positions the vision of Islam's professionalism as a paradigm in responding to reality. For experts and keen observers when it comes to discussing the relevance and religious depth, emphasizing the prophetic aspect as a very important aspect in literary works [6]. This aspect needs to be studied and explored because in the creation of a literary work the prophetic dimension becomes a meeting point between the social and transcendental dimensions. What is meant by social dimension is the dimension that refers to the profane human life, while the transcendental dimension is the dimension that refers to the higher purpose of life, culminating in the Unseen. It is this transcendental dimension that gives depth to a work, supports it with spiritual values, makes a work of art vertical or high. The prophetic dimension refers to the realm of ethics and social behavior [7]. Thus, research on this prophetic dimension is very important to do. The purpose of this study is to describe the prophetic dimension contained in the Api Tauhid novel by Habiburrahman El Shirazy is described in three aspects namely humanization, liberation, and transcendence. To identify and express the prophetic dimension in this Api Tauhid novel, the prophetic perspective of Kuntowijoyo's prophetic literature is used.

\section{METHOD}

This research method is a descriptive qualitative method. Qualitative research is a research procedure that produces description data in the form of written or oral words from people or actors that can be observed [8]. This method uses a literature review strategy by studying a text. The data source of this study is the ApiTauhid novel by Habiburrahman El Shirazy (XVII Prints October 2018), published by the Publisher Republic. While the data is the prophetic dimension contained in the novel. To reveal and describe the prophetic dimension, Kuntowijaya's perspective of Prophetic Literature is used.
Data collection in this research uses a documentation study or literature review. A document study technique is a data collection technique that produces important notes, which relate to the problem under study [9]. In this case, the researcher chooses, determines, reads, prescribes, records, and collects data from various sources, which relate to the reference to the prophetic dimension to strengthen the understanding, explanation, and interpretation of the data. The validity (validity) of the data is tested through triangulation. Triangulation is defined as checking data from various sources in various ways, and at various times[10]. Thus there is a triangulation of sources, triangulation of data collection techniques, and time. Data analysis techniques in this study refer to the opinion of Miles and Hubermen. Data analysis techniques include three activities that occur simultaneously, namely data reduction, data presentation, and conclusions or verification [11].

\section{RESULT AND DISCUSSION}

The prophetic mission contains three main elements namely humanization, liberation, and transcendence. The prophetic dimensions contained in the Api Tauhid novel by Habiburrahman El Shirazy are as follows:

\section{Humanization}

Humanization is the derivation of Ali Imran verse 110, amar ma'ruf. Its original meaning is to uphold goodness, the purpose of which is to elevate human dimensions and positive potential to emancipate towards the light of God's guidance in the course of attaining his fitrah. Humans are noble beings by their nature [4]. The word humanization comes from the Latin meaning "human beings" or "the condition of being human". Thus, humanization means humanizing humans. Humanization is an understanding that directs individuals to do good things. This refers to efforts to foster a sense of humanity [12]. In the Indonesian context, literature is seriously involved in voicing humanization based on religion, morality, and ethics. Literature is part of the subcultural wave of history besides economics, politics, and law, as the basis of humanization. The humanization dimension contained in Habiburrahman El Shirazy's Api Tauhid novel can be seen in the following quotations:

“... Maka ia persilakan masuk. Dan mau tidak mau, pintu pun ia tutup untuk menghalangi udara dingin masuk." (Shirazy, 2019: 103).

"... Then let him enter. And like it or not, he closes the door to prevent cold air from entering. "(Shirazy, 2019: 103). 
In the quote, Aysel knocked on the door of the villa and was opened by Fahmi. Aysel asked for permission to enter and explained that the temperature outside was very cold. Fahmi also felt sorry if she had to endure the cold outside. So he was allowed to enter, even though Fahmi did not know who the woman was. Aysel also did not explain who he was and what his business to the villa. This illustrates the reflection of a humanitarian Fahmi, that there is no need to see someone who is a person who is known or not if someone needs help, then it must be helped.

“... Badiuzzaman membagi remukan rotinya kepada semut-semut yang ada di situ.” (Shirazy, 2019: 210).

"... Badiuzzaman divides the crumbs of the bread to the ants there" (Shirazy, 2019: 210).

The text illustrates that sharing is not only with fellow human beings but also with animals that are God's creatures. Badiuzzaman shares the food he eats with ants. This quote illustrates that animals are also treated with respect like humans who need food and drink.

"Allah ma'aki insya Allah, laa takhaafi wa laa tahzanii hadzihi aghla syai'in indi khudzi, tafadhalil!"(Allah bersamamu, jangan takut dan sedih, ini barang paling berharga yang ada padaku, ambillah, silakan!) (Shirazy, 2019: 297).

"Allah ma'akiinsya Allah, laa takhaafi wa laa tahzanii hadzihi aghla syai'in indi khudzi, tafadhalil!" (God is with you, do not be afraid and sad, this is the most valuable item obtained, take it, please!)Shirazy, 2019: 297).

Fahmi is shocked by a woman who claims to be a Syrian refugee and asks for her help. Fahmi without thinking, immediately let go of his watch to help the mother. Fahmi gives her an expensive watch because that's the only valuable item she has. This quote contains the value of humanization, which is to help other people who get into trouble.

"Fahmi tidak tega.Ia hendak membangunkan Hamza tapi dilarang Aysel. Aysel tidak mau mengganggu yang sedang tidur.Aysel kembali masuk kamar mandi sambil memegangi perutnya.Fahmimenujudapur, iamenggodok (merebus) air panasdanmembuatteh." (Shirazy, 2019: 408).

"Fahmi does not have the heart. He was about to wake Hamza but was banned by Aysel. Aysel did not want to disturb the sleeping one. Aysel returned to the bathroom while holding her stomach.Fahmi headed for the kitchen, he boiled (boiled) hot water and made tea. "(Shirazy, 2019: 408).
Fahmi who knows that Aysel has a stomachache initiative to make warm tea for Aysel. That he did so that Aysel could recover. Fahmi wants to help Aysel. On the other hand, the humanization dimension is also illustrated by Aysel's attitude of not wanting to disturb Hamza's rest. Aysel looks at Hamza who is resting. Aysel's attitude shows tolerance for Hamza's resting rights.

Based on the above quotations, the humanization dimension in the ApiTauhid novel covers aspects, please help to fellow humans and animals around, and respect for others.

\section{Liberation}

Liberation is a derivation of the term nahimungkar (preventing mungkar). Nahimungkar means to prohibit or prevent any crime. For example, preventing friends from taking drugs, banning brawls, prohibiting gambling and stealing, combating corruption and so on.Nahimungkar also means liberation from ignorance, poverty, or oppression. Thus, knowledge systems, social systems, economic systems, and political systems that bind humans are targets of liberation. If the four systems fetter humans, then humans cannot actualize themselves as free and noble beings[13]. The liberation of knowledge systems is an effort to liberate from materialistic knowledge systems and structural donations. Liberation from the shackles of the social system is liberation from the industrial social system. The liberation of the economic system is to free people from economic disparities that occur in society. Political liberation means freeing the system of authoritarianism, dictatorship, and neofeudalism.

The dimension of liberation in the ApiTauhid novel can be seen from the following quote:

Said Nursi merasa cara menyelamatkan negara yang sakit itu adalah dengan cara menghilangkan praktikpraktik tata cara pemerintahan absolut dan sesuka-suka itu. Diganti dengan suasana bernegara yang merdeka, bebas dan berkonstitusi (Shirazy, 2019: 241).

Said Nursi felt that the way to save the ailing country was by eliminating the practices of absolute and arbitrary governance procedures. Replaced by an independent, free and constitutional state atmosphere (Shirazy, 2019: 241).

The quote indicates a form of liberation in the political system. What is meant by Said Nursi is the political system of the Ottoman Caliphate. Said Nursi did not want any arbitrary governmental system and practice without considering the people's aspirations. So he seeks to free the shackles of the political system towards government and a free, independent and constitutional state. 
"Wahaisekalianumat Islam.Sesungguhnya meminum arak itu hukumnya haram."Ia lantas membacakan ayat Al-Qur'an dan hadis berkenaan larangan meminum arak. Kemudian mendekati gubernur Omer Pasya, "Bagaimana anda mau mengatur propvinsi ini, sementara akal dan pikiran anda dikuasai arak? (Shirazy, 2019: 257).

"O Muslims! Actually, drinking wine is forbidden. "He then recited verses of the Qur'an and the hadith regarding the prohibition of drinking wine. Then approached governor Omer Pasya, "How do you want to regulate this province, while your mind and mind are controlled by wine? (Shirazy, 2019: 257).

This quote describes an action to prevent a crime or crime from happening. Said Nursi seeks to free the fetter of alcohol in Governor Omer Pasya. He advised Omer Pasya so that he was aware that drinking his wine was unlawful, and the influence of wine was very bad for survival. This quote contains the liberation of the social system.

"Karena itulah saya ingin membawanya ke Van. Dengan kehadirannya di sana, semoga lahir banyak ulama di sana. Semoga akan lahir pula beberapa orang ulama di sana." (Shirazy, 2019: 261).

"That's why I want to take him to Van. With his presence there, hopefully, many scholars will be born there. Hopefully, some scholars will be born there. "(Shirazy, 2019: 261).

Van Governor HasanPasya wanted to free his province from ignorance by bringing Said Nursi there and teaching there. With the presence of Said Nursi in Van province, the Van generation will be able to learn from Said Nursi. There will be educational institutions opening up there. Thus, the Van Generation will be free from ignorance and ignorance. This is an example of the liberation of the knowledge system.

"Kalauada yang bisasayabantu, dengansenanghati, baiksebagai pribadi dan sebagai gubernur, saya akan bantu. Ustadzjanganseganuntukmenyampaikannya."

"Kebetulansekali. Di Van ini banyak anak-anak muda yang haus ilmu pengetahuan. Saya berencana ingin mendirikan madrasah di sini..." (Shirazy, 2019: 290).

"If there is anything I can help, I will be happy, both as a person and as a governor, I will help. Ustadz, don't be afraid to say it. "

"It is such a coincidence. In this Van, many young people are hungry for knowledge. I plan to establish a madrasa here ... "(Shirazy, 2019: 290).

In the quote Governor Van, namely, ThahirPasya offered to help Ustadz Said Nursi, then Said Nursi expressed his desire to establish a school or madrasa so that the Van generation could go to school and study. This effort is a structural effort in freeing the Van generation from ignorance and ignorance. The liberation of this knowledge system is not only done by Said Nursi but also done by ThahirPasya.

Setelah madrasah-madrasah itubermunculan, Badiuzzaman Said Nursimemikirkan kelanjutan para pelajar ke tingkat lebih tinggi. Maka tercetuslah gagasan untuk mendirikan sebuah universitas yang ia namai Madrasatul Zahra, yang ia harapkan akan menjadi saudara kembar Universitas Al Azhar Mesir. Badiuzzaman Said Nursi menyampaikan gagasan itu padagubernurThahirPasya (Shirazy, 2019: 294).

After the madrasa appeared, Badiuzzaman Said Nursi thought about the continuation of students to a higher level. Then the idea arose to establish a university which he named Madrasatul Zahra, which he hoped would become a twin brother of Al Azhar University in Egypt. Badiuzzaman Said Nursi conveyed the idea to governorThahirPasya (Shirazy, 2019: 294).

Said Nursi's efforts to develop the next generation did not stop at establishing madrasas and teaching there. He thinks that the continuation of the transformation of science must be continued, namely by encouraging the establishment of a university so that children who have graduated from school can continue to a higher level. This quote is also included in the liberation of knowledge systems.

"Di Barla itu pula Said Nursi paling banyak menulis kalimat-kalimat bercahayanya yang merupakan pantulan ruh Al-Qur'an yang kemudian dikenal dengan nama Risalah Nur" (Shirazy, 2019: 479).

"InBarla, Said Nursi also wrote the most illuminating sentences which were reflections of the spirit of the Qur'an which became known as RisalahNur" (Shirazy, 2019: 479).

In addition to establishing schools and universities, Said Nursi strives to educate the people through his writings. When he was in prison, he could no longer teach his students freely. So the liberation of the knowledge system he does is by writing and spreading it. His writing will enlighten the reader.

\section{Transcendence}

Transcendence is a derivation of the term tu'minunabillah which means to believe in Allah. Transcendence is what gives understanding in the form of human awareness of God [14]. With this understanding, it is expected that humans can always build a close relationship with God, also His creatures. This will have an impact on divine values to become 
something inseparable from human life. The dimension of transcendence becomes the peak of human consciousness, this peak will harmonize human consciousness with its behavior. There are three elements of transcendence as revealed by Roger Garaudy, namely: (1) the recognition of human dependence on their Lord; (2) there is an absolute difference between God and humans; and (3) acknowledgment of the existence of absolute norms from God [3]. Transcendence is the relationship between humans and God [15]. Transcendence is also an axiological, a standard of behavior and a code of ethics that is universal [16]. The ideals of transcendence will create a longing for eternal life (life in the hereafter). The logical consequence of this ideal is the emergence of an awareness of transcendence, where someone will long to be closer to God, as in the following quote:

"Siang malam ia mematri diri, larutdalammunajatdantaqarrubkepada Ilahi. Ia itikaf di bagian selatan masjid, agak jauh dari Raudhah tapi masih termasuk shaf bagian depan." (Shirazy, 2018: 1).

"Day and night he brazed himself, dissolved in Munajat and taqarrub to the Divine. He i'tikaf in the southern part of the mosque, some distance from Raudhah but still including the front of the shaf. "(Shirazy, 2018: 1).

This quote illustrates that Fahmi is praising Allah. He dissolves in i'tikaf. He was solemn in his worship chanting verses of the Holy Qur'an. What was done by Fahmi above is part of an effort to get closer to God.

A servant who has an awareness of transcendence will believe that all life in this world has been arranged by God, for example about death. In the Qur'an, it is stated that everyone who lives will surely feel death, but the mystery of death is only God who knows when and how death will come. This is illustrated in the following quote:

"Nyawaku ada dalam genggaman Allah, aku akan mati jika sampai ajalnya.” (Shirazy, 2018: 227).

"My life is in the grasp of God, I will die if I die." (Shirazy, 2018: 227).

A person who has a good aqeedah and monotheism, will not be afraid if threatened with death by another human being. Because the problem of death is only God who knows. This will lead people to the belief that humans should not be afraid of humans. A pious servant is only afraid of Allah.

The awareness of transcendence in the servant will direct man to hope in his Lord. He depends on it, as stated in the following quote:

"Ya Allah dengan cinta kami kepada Baginda Nabi, dan dengan cinta kami kepada para syuhada Uhud, berilah kesembuhan untuk saudara kami tercinta, Fahmi. Sadarkan dia, sembuhkan dia. Jangan Engkau uji dia dengan sakit yang ia tiada kuat menanggungnya. Beri dia afiyah di dunia dan akhirat, amin." (Shirazy, 2018: 1314).

"O Allah, with our love for His Majesty the Prophet, and with our love for the martyrs of Uhud, give healing to our beloved brother, Fahmi. Awake him, heal him. Don't test him with pain that he cannot bear. Give him afiyah in the world and the hereafter, amen. "(Shirazy, 2018: 13-14).

As a friend of Fahmi, Ali is always in times of joy and sorrow. In the quote, sincerely Ali prayed for his roommate after the Fajr prayer. This quote shows the attitude of Ali who was very hopeful ( $\left.\mathrm{raja}^{\prime}\right)$. And he only hopes to rest on Allah Almighty, who is curing illness.

This quote illustrates that a servant who prays to God for the healing of his friend. That is, humans do not have power and power, but only Allah. This indicates that humans acknowledge that there is an absolute difference between humans and slaves and acknowledge their dependence on God. Humans can only try, while the decision is God. Generally, human dependence on God is narrated in prayer. Because prayer is a process of touching transcendent spaces.

"Laluakuputuskanbahwaakuhanyaakanmengadukankesed ihankuitukepada Allah" (Shirazy, 2018: 68).

"Then I decided that I would only report my sadness to God" (Shirazy, 2018: 68).

Fahmi, who was saddened by her father-in-law, Kiyai Arselan, asked her to divorce the wife he loved and loved, to establish herself for the fame of the Nabawi Mosque. He feels only to God that all matters are returned. He resigned and resigned to all the events that took over. This is the attitude of the obedient servant, that everything will be returned to Him, the owner of the universe and the almighty over everything. Fahmi realizes that Allah knows all the events in the world, that the events he is experiencing. Allah is the one who knows his feelings better, so he only complains about his sadness to God. He was patient in facing the trials that swept over him. The ordeal did not frustrate him, instead brought him closer to God. He put his trust in Allah.

Tiba-tiba ia merasa sangat bersyukur kepada Allah, karena memberi kesempatan untuk sampai di kota Instanbul, kota yang dulu bernama Konstantinopel, ibu kota imperium Byzantium (Shirazy, 2018: 90).

Suddenly he felt very grateful to God, for allowing him to arrive at the city of Istanbul, the city that was once called 
Constantinople, the capital of the Byzantine empire (Shirazy, 2018: 90).

The quote explicitly illustrates that Fahmi was very grateful for Allah's blessings, that he could visit Istanbul, the city that was once conquered by Muhammad Al-Fatih in 1453. As a servant, thanking for God's favor is a suggestion, even in the Qur'an, Allah asserts that whoever is thanking His favors will add His favors.

Fahmi terus berdzikir. Kepada Allah, berdoa dalam hati sampai menangis, "Ya Allah, aku menghafal kitab suciMu semata-mata demi meraih ridha-Mu. Jangan Kau izinkan daging, dan darah yang digunakan untuk menghafal kitab suci-Mu ini dimakan anjing, ya Allah." (Shirazy, 2018: 537).

Fahmi continues to dhikr. To God, pray silently until you cry, "O God, I have memorized Your holy book solely to win Your pleasure. Do not you allow the flesh, and blood used to memorize your holy book to be eaten by dogs, $\mathrm{O}$ God. "(Shirazy, 2018: 537).

This quote shows the sincerity of Fahmi, he memorizes the Qur'an solely to get divine pleasure. This is the concept of sincerity in Islam, doing something only because of Allah, not because of anything else.

Transcendence awareness in the Api Tauhid novel can also be seen from the narrative of bismillah pronunciation. In Islam, an activity begins with reading basmalah. This is a description of the transcendence aspect, where human behavior is always connected with God. Furthermore, there is a representation of the dimension of transcendence in the novel in the form of the pronunciation of God when feeling something of awe. Say insya Allah when promised, realize that all events in this world at the will of Allah Almighty. Insya Allah, is an absolute recognition that human life depends on God's provisions. Next, say alhamdulillah as a form of human gratitude for the favors that God has given. The favors given by Allah cannot be counted. Saying hamdalah is a form of gratitude that is recommended in Islam. Saying istirja to recognize that the human soul is in the grasp of God, and Allah is the almighty power of killing His creatures.

The dimensions of transcendence in the ApiTauhid novel by Habiburrahman El Shirazy include patience, fear of Allah (khauf), very hopeful (raja'), surrender (tawakkal), gratitude, and sincerity.

\section{CONCLUSION}

The Api Tauhid novel by Habiburrahman El Shirazy contains a prophetic dimension namely humanization, liberation and transcendence. The prophetic dimension is a term put forward by Kuntowijaya based on his interpretation of Surah Ali Imran verse 110, namely amar ma'ruf, nahi mungkar, and tu'minuna billah. humanization in the novel includes aspects of please help and an attitude of respect for others. Please help in terms of humanization not only for humans but also for animals. Dimensions of liberation that arise in the form of liberation of knowledge systems, social systems, and political systems. While the transcendence dimension includes aspects of patience, fear of Allah (khauf), very hopeful (raja'), surrender (tawakkal), gratitude, and sincerity.

\section{REFERENCES}

[1] Kuntowijaya, Maklumat Sastra Profetik. Yogyakarta: Grafindo Litera Media, 2006.

[2] Muhammad Iqbal, Rekonstruksi Pemikiran Religius dalam Islam. Bandung: Mizan, 2016.

[3] R. Garaudy, Janji-Janji Islam. Jakarta: Bulan Bintang, 1982.

[4] Kuntowijaya, Paradigma Islam: Interpretasi untuk Aksi. Bandung: Mizan, 1991.

[5] Teguh Trianton, "Estetika Profetik Ahmad Tohari dalam Khazanah Budaya Cablaka," Ibda, vol. 11, no. 2, pp. 211226, 2013.

[6] A. Hadi, Hermeneutika, Estetika, dan Religiusitas: Esai-esai Sastra Sufistik, dan Seni Rupa. Jakarta: Sadra Press, 2016.

[7] S. Briefs and I. N. Religious, Springer Briefsin Religious Studies Violence in Southern Sport and Culture Sacred Battles on the Gridiron. .

[8] L. J. Moleong, Metode Penelitian Kualitatif, Revisi. Bandung: PT. Remaja Rosdakarya, 2016.

[9] Basrowi dan Suwandi., Memahami Penelitian Kualitatif. Jakarta: Rineka Cipta, 2008.

[10] Sugiyono, Metode Penelitian Kuantitatif, Kualitatif, dan $R \& D$. Bandung: Alfabeta, 2016.

[11] M. B. Miles and M. A. Huberman, Analisis Data Kualitatif: Buku Sumber Tentang Metode-Metode Baru. 2014.

[12] Masbur, "Integrasi Unsur Humanisasi, Liberasi dan Transendensi dalam Pendidikan Agama Islam," Edukasi, vol. 2, no. 1, pp. 44-59, 2016.

[13] Kuntowijaya, Islam Sebagai Ilmu. Yogyakarta: Tiara Wacana, 2007.

[14] M. Roqib, Prophetic Education: Kontekstualisasi Filsafat dan Budaya Profetik dalam Pendidikan. Purwokerto: STAIN Press, 2011.

[15] D. Sulaksono, B. Waluyo, and D. P. Said, "Prophetic Valuesin Post-Reform Modern Javanese Novel," el Harakah, vol. 20, no. 1, pp. 81-98, 2018.

[16] Dkk Hanafi, Islam dan Humanisme: Aktualisasi Humanisme Islam di Tengah Krisis Humanisme Universal. Yogyakarta: Pustaka Pelajar, 2007. 